\title{
Digital geological map and geochronological database of the Cenozoic cover of the southern Mesa Central province, Mexico ${ }^{\text {th }}$
}

\section{Mapa geológico digital y base de datos geocronológica de la cobertura cenozoica del sur de la provincia Mesa Central, México}

\author{
Alexis Del Pilar-Martínez*a,b, Ángel F. Nieto-Samaniego ${ }^{\mathrm{b}}$, Edgar Angeles-Moreno ${ }^{\mathrm{c}}$, Ana M. Suárez-Arias ${ }^{\mathrm{d}}$, María de Jesús \\ Paulina Olmos-Moya ${ }^{\mathrm{d}}$, Susana A. Alaniz-Álvarez ${ }^{\mathrm{b}}$, Gilles Levresse ${ }^{\mathrm{b}}$ \\ ${ }^{a}$ Estación Regional del Noroeste, Instituto de Geología, Universidad Nacional Autónoma de México, Hermosillo, 83000, México \\ ${ }^{b}$ Centro de Geociencias, Universidad Nacional Autónoma de México, Campus Juriquilla, Querétaro, 76230, México \\ ${ }^{c}$ Departamento de Ingeniería en Minas, Metalurgia y Geología, Universidad de Guanajuato, Guanajuato, 36020, México \\ ${ }^{d}$ Posgrado en Ciencias de la Tierra, Centro de Geociencias, Universidad Nacional Autónoma de México, Querétaro, 76230, México
}

\begin{abstract}
The digital geological map of the southern sector of the Mesa Central province is presented, covering an area of $41000 \mathrm{~km}^{2}$ in central Mexico. This first interactive map is a compilation of the geological maps available in the literature and the unpublished maps done by our work team. The map focuses on the Cenozoic stratigraphy, supported by a geochronological database of 261 isotopic ages derived from $\mathrm{K}-\mathrm{Ar}, \mathrm{U}-\mathrm{Pb}, \mathrm{Ar}-\mathrm{Ar}$, and fission tracks methods. The interactive map displays the lithostratigraphic and chronostratigraphic units and the major and second-order Cenozoic faults. Map construction considered lithostratigraphy and geochronological correlation criteria and the main unconformities. Integrating these data in a single digital map allows a regional vision of the southern Mesa Central, making the map a valuable work tool to better understand the Cenozoic geologic evolution of central Mexico.
\end{abstract}

Keywords: Mesa Central province, interactive geological map, geochronological database, Central Mexico, Cenozoic stratigraphy

\section{Resumen}

Se presenta el mapa geológico digital del sector sur de la provincia Mesa Central, cubriendo un área de $41000 \mathrm{~km}^{2}$ en el centro de México. Este primer mapa interactivo es una compilación de los mapas geológicos disponibles en la literatura y de los mapas inéditos realizados por nuestro grupo de trabajo. El mapa se enfoca en la estratigrafía cenozoica, apoyada por una base de datos geocronológicos de 261 edades isotópicas K-Ar, U-Pb, Ar-Ar y trazas de fisión. El mapa interactivo muestra las unidades litoestratigráficas y cronoestratigráficas, y las fallas cenozoicas mayores y de segundo orden. La construcción del mapa consideró criterios de correlación litoestratigráficos, geocronológicos y las discordancias principales. La integración de esta información en un mapa digital unificado permite una visión regional del sur de la Mesa Central, haciendo del mapa una herramienta de trabajo valiosa para un mejor entendimiento de la evolución geológica del centro de México.

Palabras clave: Provincia Mesa Central, mapa geológico interactivo, base de datos geocronológica, centro de México, estratigrafía cenozoica

(C) A. Del Pilar-Martínez, Á. F. Nieto-Samaniego, E. Angeles-Moreno, A. M. Suárez-Arias, M. de J. Paulina Olmos-Moya, S. A. Alaniz-Álvarez, G. Levresse
This work is licensed under a Creative Commons "Attribution-NonCommercial-ShareAlike 4.0 International" license.

\footnotetext{
*E-mail address: adelpilar@geologia.unam.mx
} 


\section{Introduction}

The Mesa Central province (MC) forms an elevated plateau at an average $2000 \mathrm{~m}$ above sea level in central Mexico (Figure 1). This province is characterized by an extensive Cenozoic continental volcanic and clastic cover affected by extensional deformation (Nieto-Samaniego et al., 2007). A major angular unconformity (Upper Cretaceous-Paleocene) separates two stratigraphic groups associated with different tectonic regimes. Below the unconformity, the pre-Cenozoic rocks are affected by shortening structures related to the building of the Mexican orogen (Fitz-Díaz et al., 2018), which ceased between 73-52 Ma in a broad region of the southern MC (Tristán-González et al., 2009b; Cuéllar-Cárdenas et al., 2012; Angeles-Moreno et al., 2017; Nieto-Samaniego et al., 2020). Above the unconformity, the Cenozoic rocks are affected by the Basin and Range extensional tectonics and consist of continental sedimentary and magmatic successions (Figure 2). Eocene rocks include conglomerates and intermediate to silicic ignimbrites and lavas, followed by a voluminous succession of Oligocene silicic ignimbrites and rhyolites. Miocene-Quaternary andesites and basalts occur in the upper part of the stratigraphic column (Nieto-Samaniego et al., 2007). At a more regional scale, the Oligocene rocks are part of the ignimbrite flare-ups that occurred at 32-28 Ma and 24-20 Ma in western-central Mexico, building the the Sierra Madre Occidental silicic large igneous province (Ferrari et al., 2002; 2007).

Besides the major Upper Cretaceous-Paleocene unconformity, other second-order unconformities (Lutetian-Priabonian, Priabonian-Rupelian, Rupelian-Chattian, and Miocene) have been documented and used to organize the stratigraphy in the southern MC (Figure 2). These unconformities mark episodes of volcanic quiescence with changes in the volcanic style and composition, associated with regional tectonic events (NietoSamaniego et al., 2007; Angeles-Moreno, 2018). Recently, Del Pilar-Martínez et al. (2020a; 2020b) documented that the limit Rupelian-Chattian coincides with a change in the deformation style, which evolved from biaxial domino-like faulting to triaxial polymodal faulting.

Many authors addressed the Cenozoic stratigraphy and geologic cartography of the MC (Figure 1). Particularly, in the past decade a great effort has been made to provide new geological maps with a stratigraphic framework supported by isotopic ages, which allowed a refinement and a better understanding of the geologic evolution of the MC. In this contribution, we integrated the geological maps available in the literature and compiled a comprehensive geochronologic database. With this information, we elaborated a digital interactive map encompassing the whole southern sector of the MC, which is limited by regional structures: the San Luis-Tepehuanes fault system to the north, the El Bajío fault system to the south, the TaxcoSan Miguel de Allende fault system to the east, and the Aguascalientes graben to the west. The mapped area comprises part of the states of Guanajuato, San Luis Potosí (S. L. P.), Jalisco, Aguascalientes, and Zacatecas, covering an area of approxi- mately $41000 \mathrm{~km}^{2}$.

\section{Methods}

The compilation included geological data from LabartheHernández et al. (1982), Loza-Aguirre et al. (2008), TristánGonzález et al. (2015), González-Cervantes et al. (2019), Del Pilar-Martínez et al. (2020b), and Sieck et al. (2021) (Figure 1), and the unpublished theses of Ruiz-González (2015), OlmosMoya (2016), Angeles-Moreno (2018), Suárez-Arias (2019), and Del Pilar-Martínez (2021). In the areas not covered by these works, we used the geological maps at 1:50 000 scale (Table 1) published by Servicio Geológico Mexicano (SGM) available at https://www.gob.mx/sgm. The pre-Cenozoic rocks were grouped in a single unit as "Mesozoic rocks". Because of the large number of Cenozoic lithostratigraphic units (formal and informal), we group them in several chronostratigraphic units as shown in Figure 3, based on the International Chronostratigraphic Chart 2021/05 (Cohen et al., 2021). The map is supported by 261 isotopic ages: $125 \mathrm{~K}-\mathrm{Ar}, 95 \mathrm{U}-\mathrm{Pb}, 29 \mathrm{Ar}-\mathrm{Ar}$, and 3 fission-tracks (see the supplementary information). The ages were compiled from published papers, technical reports, and theses. Data georeferencing and digitization were done using ESRI ArcMap. We carefully verified and traced the geologic contacts as well as the major and second-order extensional faults, ensuring the consistency between isotopic ages and the correspondent chronostratigraphic unit. Google Earth satellite images (Map data: (C)2021 Maxar Technologies), digital elevation models from Earth Explorer (https://earthexplorer.usgs.gov), and topographic maps from the Instituto Nacional de Estadística y Geografía (INEGI) were used for a more precise drawing of contacts and faults. The final static map layout and figures were elaborated using CorelDRAW X7®.

\section{Cenozoic magmatism and extension in the southern Mesa Central province}

\subsection{Eocene}

\subsubsection{Ypresian-Lutetian}

The lower Eocene record comprises continental sediments interbedded with volcanic rocks and granitic intrusions, reported in several localities in the MC (Figure 3). The volcanic rocks consist of lavas and ignimbrites with the composition varying from andesite to rhyolite, which represent the onset of volcanism after the end of the Laramide orogeny (Cuéllar-Cárdenas et al., 2012; Angeles-Moreno et al., 2017). Sieck et al. (2021) reported a small outcrop in the Villa García-Loreto region (Zacatecas state) with the oldest (60.4 Ma) volcanic rocks with a subduction signature in the MC, which they named La Milpa Andesite. In the Sierra de Guanajuato (SG), the Ypresian volcanic rocks, including the Laborcita rhyolite, Duarte dike-strata, and Palo Blanco ignimbrite, were mapped by Angeles-Moreno (2018) and Ruiz-González (2015). Aranda-Gómez and McDowell (1998) reported andesitic lavas of $49 \mathrm{Ma}$ interbedded 


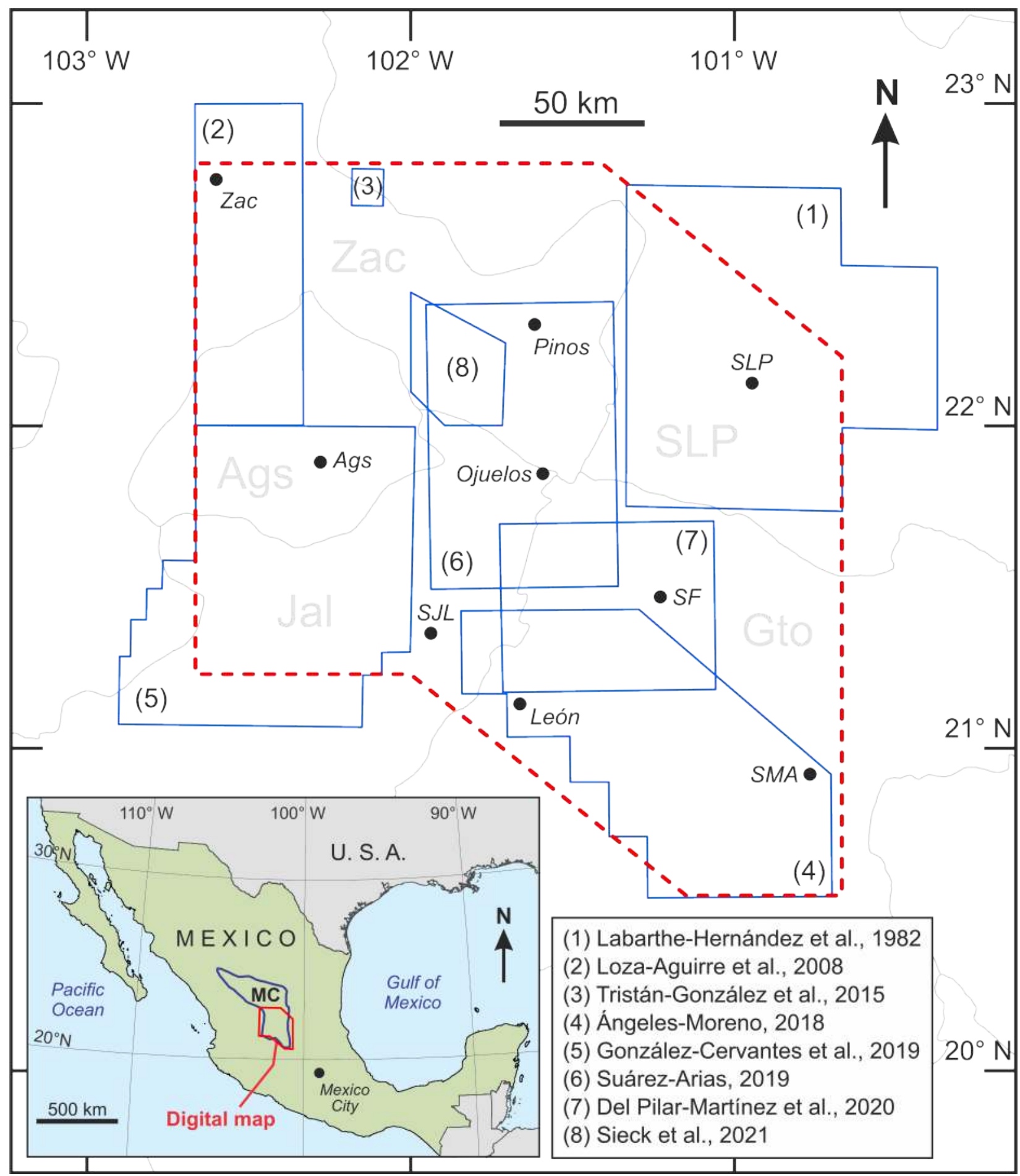

Figure 1: Location of the study area. The inset map displays the location of the Mesa Central province in central Mexico. The red polygon with a dashed line is the mapped area, and the blue polygons are the available published maps compilated to construct this map. The gray lines are the state boundaries, and the black dots are the main localities. MC: Mesa Central province, Zac: Zacatecas, Ags: Aguascalientes, SJL: San Juan de los Lagos, SF: San Felipe, SLP: San Luis Potosí, SMA: San Miguel de Allende. / Figura 1: Localización del área de estudio. El mapa muestra la localización de la provincia Mesa Central en el centro de México. El polígono rojo con línea punteada es el área mapeada y los polígonos azules son los mapas publicados disponibles para construir este mapa. Las líneas en gris son los límites estatales y los puntos en negro son las localidades principales. MC: provincia Mesa Central, Zac: Zacatecas, Ags: Aguascalientes, SJL: San Juan de los Lagos, San Felipe, SLP: San Luis Potosí, SMA: San Miguel de Allende. 


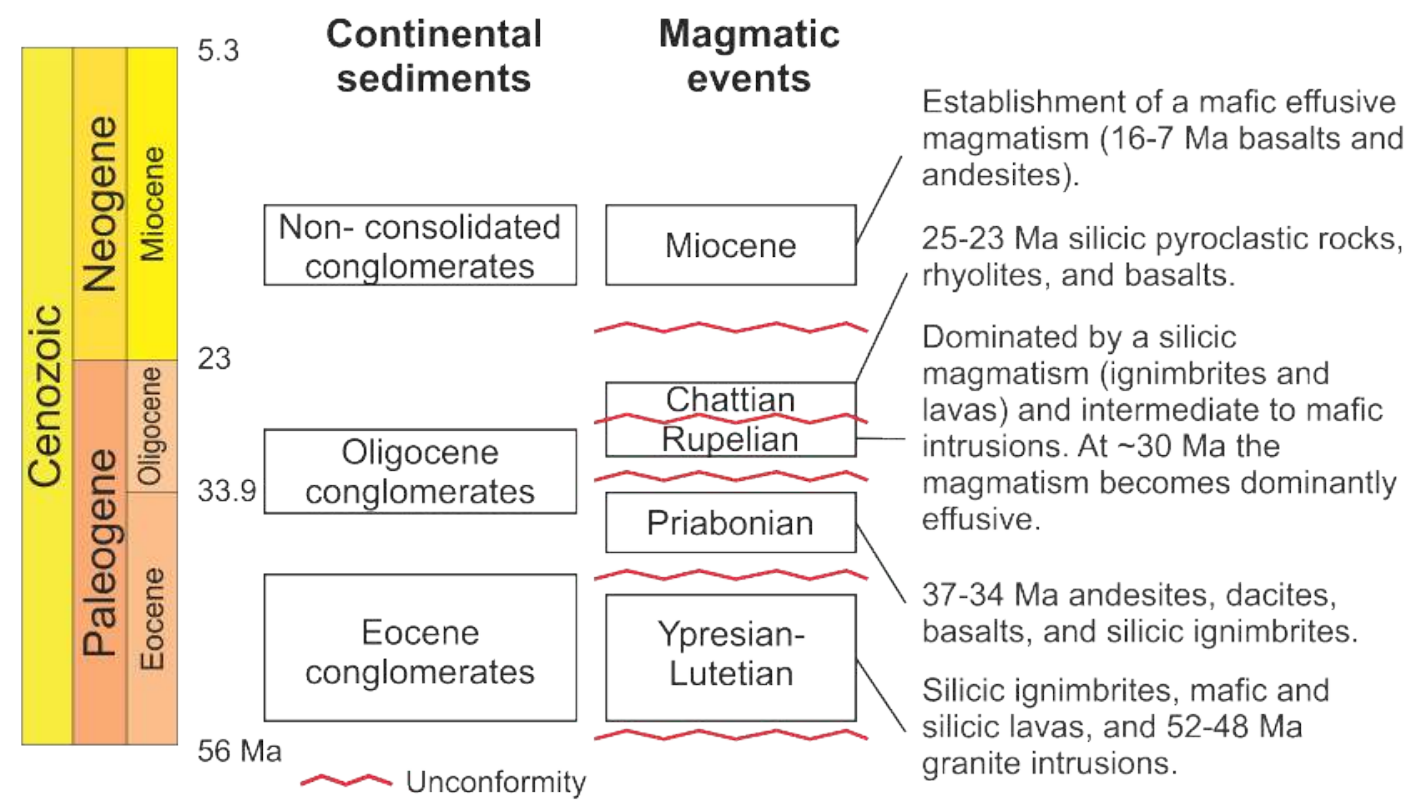

\section{Extensional phases}

Extension NE-SW and NW-SE

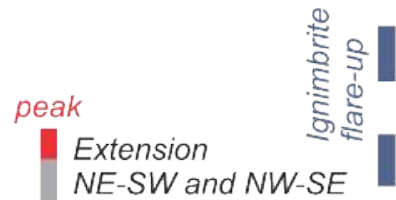

Extension

NE-SW

Transition

shorteningextension

Figure 2: Cenozoic stratigraphic synthesis and deformation events from the southern Mesa Central. The information was taken from Alaniz-Álvarez et al. (2001), Ferrari et al. (2002), Aranda-Gómez et al. (2007), Nieto-Samaniego et al. (2007), Cuéllar-Cárdenas et al. (2012), Angeles-Moreno et al. (2017), Angeles-Moreno (2018), Del Pilar-Martínez et al. (2020a; 2020b), and Del Río-Varela et al. (2020). / Figure 2: Síntesís estratigráfica y eventos de deformación cenozoicos del sur de la Mesa Central. La información fue tomada de Alaniz-Álvarez et al. (2001), Ferrari et al. (2002), Aranda-Gómez et al. (2007), Nieto-Samaniego et al. (2007), Cuéllar-Cárdenas et al. (2012), Angeles-Moreno et al. (2017), Angeles-Moreno (2018), Del Pilar-Martínez et al. (2020a; 2020b) y Del Río-Varela et al. (2020).

in the lower member of the Guanajuato Conglomerate in the Guanajuato mining district (southeastern SG). Ponce and Clark (1988) reported the 47 Ma Los Alamitos ignimbrite located near to Zacatecas city, and Loza-Aguirre et al. (2008) the El Devisador Ignimbrite (middle Eocene), the $49 \mathrm{Ma}$ La Bufa Rhyolite, and the 42 Ma Presillas Formation. Also, EscalonaAlcázar et al. (2016) dated at $43.5 \mathrm{Ma}$ the volcanic rocks of Cerro La Bufa. Tristán-González et al. (2015) reported lavas of $50 \mathrm{Ma}$ (La Leona rhyolite) and 44.5 Ma (La Cardona rhyolite) cropping out in La Tesorera region (Zacatecas state). The same authors reported volcanic rocks older than the Eocene, which termed El Gato dacite of $63 \mathrm{Ma}$; however, the new isotopic ages published by Nieto-Samaniego et al. (2020) indicated a Lutetian age $(47.5 \mathrm{Ma})$ for these rocks. Tristán-González et al. (2009a) reported an age of $44.5 \mathrm{Ma}$ for the Casita Blanca Andesite in S. L. P. Nieto-Samaniego et al. (1996) documented the $47 \mathrm{Ma}$ Presa Los Arquitos ignimbrite and the $40 \mathrm{Ma}$ El Venaderito rhyolite in the Aguascalientes region. Although there is no record of Ypresian-Lutetian volcanic rocks in the San Felipe region (Guanajuato state), the age of ca. $50 \mathrm{Ma}$ de-

Table 1: List of the geological maps 1: 50000-scale of the Servicio Geológico Mexicano (SGM) used for the compilation of this work / Tabla 1: Lista de los mapas geológicos a escala 1:50000 del Servicio Geológico Mexicano (SGM) usados para la compilación de este trabajo.

\begin{tabular}{ccc}
\hline Key & Name & Authors \\
\hline F13-B69 & Ojo Caliente & Sociedad Exploradora Minera S.A. de C.V. (1999) \\
F13-B79 & Luis Moya & GYMSA, Estudios de Planeación Regional S.A. de C.V. \\
& & (2001) \\
F12-B89 & Rincón de Romos & Torres et al. (2001) \\
F14-A61 & Salinas de Hidalgo & Hernández-Loredo (2007) \\
F14-A71 & Loreto & Gontañez-Castro and Bustos-Gutiérrez (2002) \\
F14-C31 & Lagos de Moreno & Romo-Ruíz (1999) \\
F14-A62 & Espíritu Santo & Romórez (2007) \\
F14-A72 & Pinos & Sociedad Exploradora Minera S.A. de C.V. (1999) \\
F14-C24 & Melchor & Gámez-Ordaz and Ávila-Ramos (2017) \\
F14-C34 & San Diego de la Unión & Procesos Analíticos Informáticos S.A. de C.V. (2008) \\
F14-C44 & Dolores Hidalgo & Pérez-Vargas et al. (1996) \\
\hline
\end{tabular}


rived from detrital zircons reported by Del Pilar-Martínez et al. (2020b) was interpreted as evidence of a source of Ypresian volcanism that possibly formed a lithological cover now completely eroded.

The plutonic rocks include the 62-60 Ma Cerro de San Pedro intrusive exposed in S. L. P. (Cuéllar-Cárdenas et al., 2012; Díaz-Bravo et al., 2021); the $59 \mathrm{Ma}$ Chepinque intrusive in $\mathrm{Za}$ catecas state (Franzetti, 2009); the 52 Comanja Granite in the SG (Botero-Santa et al., 2015; Angeles-Moreno et al., 2017); and the 51 Ma Peñón Blanco Granite in S. L. P. and Zacatecas states (Aranda-Gómez et al., 2007). The oldest intrusion crops out in Zacatecas state and corresponds to the 75-73 Ma Tesorera Granodiorite (Cuéllar-Cárdenas et al., 2012; TristánGonzález et al., 2015).

The Eocene continental sedimentary rocks include the Guanajuato Conglomerate and Duarte Conglomerate (Edwards,1955; Martínez-Reyes, 1992; Aranda-Gómez and McDowell, 1998; Miranda-Avilés et al., 2016), the Zacatecas Conglomerate (Esca lona-Alcázar et al., 2016), the Cenicera Formation (LabartheHernández et al., 1982), and the Pinos conglomerate (ArandaGómez et al., 2007). They contain clasts derived from intrusive rocks suggesting that intrusive bodies were exhumed contemporaneously with sedimentation during the Late Cretaceousearly Eocene. The time of exhumation overlaps with the transition between the Laramide shortening and the Basin and Range extension, associated with a crustal relaxation and gravitational collapse (Tristán-González et al., 2009b; Nieto-Samaniego et al., 2020). In northern S. L. P., this transition produced uplift of crustal blocks through strike-slip faults trending NNE and NNW (Tristán-González et al., 2009b). These faults exhumated the Triassic-Jurassic metamorphic successions and formed basins filled with the continental volcanic and clastic deposits. In the $\mathrm{SG}$, the transition was recorded in the tourmaline veins hosted in the Ypresian Comanja Granite, which display brittle-ductile deformation structures related to strike-slip faults with a small thrust component (Angeles-Moreno et al., 2017).

\subsubsection{Priabonian}

The Priabonian stratigraphic record is scarce in the southern MC. Ponce and Clark (1988) reported the 36.8 Ma La Virgen Formation near Zacatecas city. In the same region, EscalonaAlcázar et al. (2016) documented tuffs of 37 and $35 \mathrm{Ma}$ interbedded in the Zacatecas Conglomerate. Suárez-Arias (2019) documented the 34.6 Ma El Gallo rhyolite in Ojuelos region (Jalisco state). Del Pilar-Martínez et al. (2020) reported the 34.4 Ma El Aguaje Dacite in San Felipe (Guanajuato state). In S. L. P., Labarthe-Hernández et al. (1982) mapped the Jacavaquero dacite, which was assigned to the early Oligocene based on its stratigraphic position, although a late Eocene age can not be discarded.

The Priabonian pyroclastic rocks interbedded with the continental conglomerates suggest that sedimentation coeval with volcanism reached the late Eocene. Extensional structures with Priabonian age have not been documented in the MC.

\subsection{Oligocene}

The Oligocene volcanism is the most abundant in southern and western MC (Labarthe-Hernández et al., 1982; Ferrari et al., 2007; Nieto-Samaniego et al., 2007; Tristán-González et al., 2009a). It comprises mainly silicic volcanic rocks, both of effusive and explosive origin, and subordinate mafic to intermediate rocks. Oligocene granitic intrusions also have been reported and recently have been shown to be highly relevant for understanding the Oligocene geological evolution of the MC (Del Pilar-Martínez, 2021; Díaz-Bravo et al., 2021). We separated all these rocks into four chronostratigraphic units according to regional faulting events described below.

\subsubsection{Lower Rupelian}

The lower Rupelian unit comprises andesites, silicic ignimbrites, and intrusive rocks of ca. 33-31 Ma (indicated as Rupelian $_{1}$ in Figure 3 and the static map). These rocks have been reported in the states of Guanajuato, Jalisco, S. L. P., and Zacatecas. In the Guanajuato mining district, they were named Guanajuato Volcanic Group by Nieto-Samaniego et al. (2016). In the San Felipe-León-Ojuelos region this unit is represented by the $31 \mathrm{Ma}$ Alfaro, Los Juanes, and Rincón de Ortega ignimbrites, the $31 \mathrm{Ma}$ Bernalejo andesite, and the $30 \mathrm{Ma}$ Cedro Formation (Botero-Santa et al., 2015; Angeles-Moreno, 2018; Suárez-Arias, 2019; Del Pilar-Martínez et al., 2020b). In S. L. P., the $31 \mathrm{Ma}$ Santa María Ignimbrite belongs to this unit (Tristán-González et al., 2009a). In the Villa García-Loreto region this volcanism is represented by the $31 \mathrm{Ma}$ Villa García Ignimbrite (Sieck et al., 2021). On the other hand, the intrusive rocks have ages of 31-30 Ma with the composition varying from gabbro, quartz monzodiorite, and granite (LabartheHernández et al., 1982; Martínez-Reyes, 1992; Del Pilar-Martí nez et al., 2020b).

During the early Rupelian, a NW trending domino-like fault system was active in a broad region of the southern MC (Del Pilar Martínez et al., 2020a, and references therein). The domino fault-domains are well preserved in the Sierra de San Miguelito (S. L. P.), San Felipe region, and the Guanajuato mining district. The record of syn-extensional sedimentation coeval with volcanism is present in the Pinos conglomerate, which is interbedded with tuffs of $32 \mathrm{Ma}$ (Aranda-Gómez et al., 2007).

\subsubsection{Middle Rupelian}

This unit comprises voluminous silicic effusive rocks and subordinated pyroclastic successions of 30-29 Ma (indicated as Rupelian ${ }_{2}$ in Figure 3 and the static map). It marks a change in the chemical composition of the magmas in the MC, from high-K to high-silica, peraluminous, and fluorine-rich rhyolites (Orozco-Esquivel et al., 2002). The middle Rupelian unit includes the San Miguelito Rhyolite, Portezuelo Latite, Ojo Calien te Trachyte, Quelital Rhyolite, Chichíndaro Rhyolite, La Montesa Rhyolite, and Altamira rhyolite (Figure 3). Faults controlled the emplacement of these rocks because in Guanajuato and S. L. P. states, is shown by many rhyolitic lava-domes 


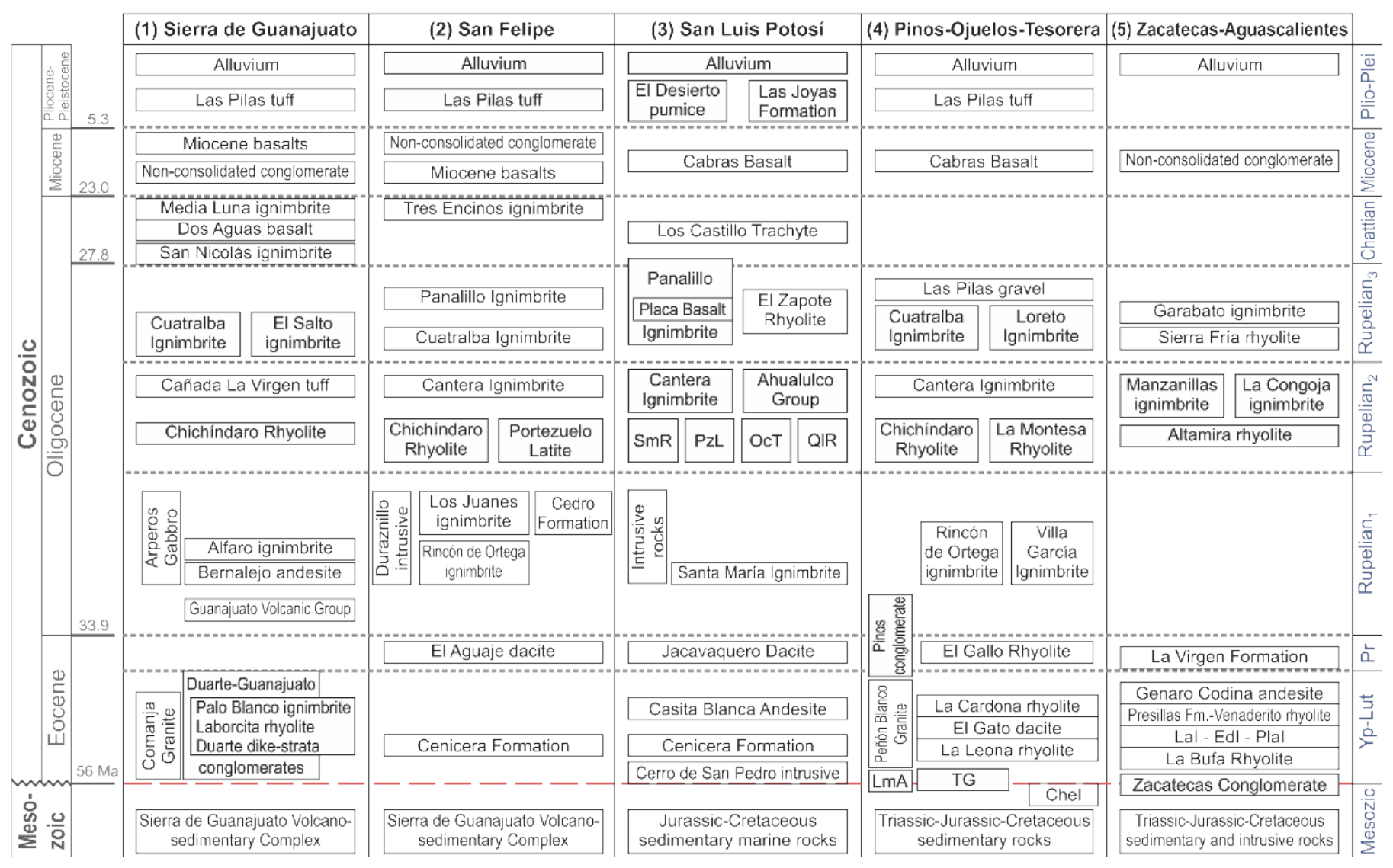

Figure 3: Simplified stratigraphic columns from the southern Mesa Central. The lithostratigraphic unit names and ages are mentioned in the text. The discontinuous lines indicate the unconformities identified in the MC, which were used to define the chronostratigraphic units indicated in blue text. SmR: San Miguelito Rhyolite, PzL: Portezuelo Latite, OcT: Ojo Caliente Trachyte, QIR: Quelital Rhyolite, TG: Tesorera Granodiorite, CheI: Chepinque intrusive, LmA: La Milpa Andesite, LaI: Los Alamitos ignimbrite, EdI: El Devisador ignimbrite, PlaI: Presa Los Arquitos ignimbrite, Yp-Lut: Ypresian-Lutetian, Pr: Priabonian, Plio-Plei: Pliocene-Pleistocene. References of stratigraphic columns: (1) Martínez-Reyes (1992), Nieto-Samaniego et al. (1996), Botero-Santa et al. (2015), Ruiz-González (2015), Ángeles-Moreno (2018); (2) Del Pilar-Martínez et al. (2020b); (3) Labarthe-Hernández et al. (1982); (4) Aranda-Gómez et al. (2007),

Franzetti (2009), Tristán-González et al. (2015), Suárez-Arias (2019), Sieck et al. (2021); (5) Ponce and Clark (1988), Nieto-Samaniego et al. (1996), Loza-Aguirre et al. (2008), Cuéllar-González (2016). / Figure 3: Columnas estratigráficas simplificadas del sur de la Mesa Central. Los nombres y edades de las unidades litoestratigráficas son mencionadas en el texto. Las lineas discontinuas indican las discordancias identificadas en la MC, las cuales fueron usadas para definir las unidades cronoestratigráficas señaladas en texto azul. SmR: Riolita San Miguelito, PzL: Latita Portezuelo, OcT: Traquita Ojo Caliente, QIR: Riolita Quelital, TG: Granodiorita Tesorera, CheI: intrusivo Chepinque, LmA: Andesita La Milpa, LaI: ignimbrita Los Alamitos, EdI: ignimbrita El Devisador, PlaI: ignimbrita Presa Los Arquitos, Yp-Lut: Ypresiano-Lutetiano, Pr: Priaboniano, Plio-Plei: Plioceno-Pleistoceno. Referencias de las columnas estratigráficas: (1) Martínez-Reyes (1992), Nieto-Samaniego et al. (1996), Botero-Santa et al. (2015), Ruiz-González (2015), Ángeles-Moreno (2018); (2) Del Pilar-Martínez et al. (2020b); (3) Labarthe-Hernández et al. (1982); (4) Aranda-Gómez et al. (2007), Franzetti (2009), Tristán-González et al. (2015), Suárez-Arias (2019), Sieck et al. (2021); (5) Ponce y Clark (1988), Nieto-Samaniego et al. (1996), Loza-Aguirre et al. (2008), Cuéllar-González (2016).

aligned along normal faults oriented NW-SE and NE-SW (NietoSamaniego et al., 2007; Aguillón-Robles et al., 2009; RodríguezRíos et al., 2013). The pyroclastic successions are represented by the $30 \mathrm{Ma}$ Cantera Ignimbrite and Ahualulco Group in S. L. P. (Labarthe-Hernández et al., 1982; Tristán-González et al., 2009a; 2009b), the 29 Ma Manzanillas ignimbrite in the Asientos mining district (Aguascalientes state) (Cuéllar-González, 20 16 ), and the $\sim 29$ Ma Cañada La Virgen tuff in the SG (AngelesMoreno, 2018). The ignimbrites could have been emplaced from volcanic calderas and most probably through linear fissurevents (Aguirre-Díaz and Labarthe-Hernández, 2003). Pyroclastic dikes associated to explosive eruptions were also recognized, in some case controlled by faults in the Sierra de San Miguelito and Sierra de Guanajuato (Torres-Hernández et al., 2006; Xu et al., 2013; Nieto-Samaniego et al., 2016).

All these rocks record the cessation of the domino faulting and predate the onset of the polymodal faulting documented in the southern MC (Del Pilar Martínez et al., 2020b).

\subsubsection{Uppper Rupelian}

This unit comprises pyroclastic rocks $<29 \mathrm{Ma}$, which have been documented in the central-eastern, southern, and western MC (indicated as Rupelian ${ }_{3}$ in Figure 3 and the static map). In S. L. P., they include the $28 \mathrm{Ma}$ Panalillo Ignimbrite (LabartheHernández et al., 1982; Tristán-González et al., 2009a) and the $27 \mathrm{Ma}$ El Zapote Rhyolite (Nieto-Samaniego et al., 1996). In the Sierra de Guanajuato and Sierra de Codornices, the $28 \mathrm{Ma}$ Cuatralba and El Salto ignimbrites belong to this unit (Nieto- 
Samaniego et al., 2007; Angeles-Moreno, 2018) as well as the $28 \mathrm{Ma}$ Loreto Ignimbrite in the Villa García-Loreto region (Sieck et al., 2021). In the western border of the MC are the $28 \mathrm{Ma}$ Garabato ignimbrite and the 27 Ma Sierra Fría rhyolite (LozaAguirre et al., 2008). The coeval occurrence of sedimentation and volcanism is recorded by $27 \mathrm{Ma}$ tuffs interbedded in the Las Pilas gravel, exposed in the Pinos region (Zacatecas state) (Aranda-Gómez et al., 2007).

The upper Rupelian rocks recorded the polymodal faulting that accommodated the brittle triaxial deformation in the MC (Nieto-Samaniego et al., 1999; Del Pilar Martínez et al., 2020a).

\subsubsection{Chattian}

A hiatus in volcanic activity from $27 \mathrm{Ma}$ to $23 \mathrm{Ma}$ is evident in most of the southern MC. The only exceptions are two $\mathrm{K}$-Ar ages of ca. $25 \mathrm{Ma}$ for ignimbrites exposed in the SG (San Nicolás Ignimbrite; Nieto-Samaniego et al., 1996; 2007) and S. L. P. (upper Panalillo Ignimbrite; Labarthe-Hernández et al., 1982). In the SG and San Felipe region are the $23 \mathrm{Ma}$ Media Luna ignimbrite and 23.5 Ma Tres Encinos ignimbrite, respectively (Botero-Santa et al., 2015; Del Pilar-Martínez et al., 2020b). These pyroclastic rocks are locally associated with basaltic lavas called Dos Aguas basalt (Martínez-Reyes, 1992) and La Placa Basalt (Labarthe-Hernández et al., 1982), which show the bimodal character of the late Oligocene volcanism. The Chattian rocks are slightly tilted due to the reactivation of the Rupelian faults (Botero-Santa et al., 2015; Del PilarMartínez et al., 2020b).

\subsection{Miocene}

The Miocene stratigraphic record comprises clastic sedimentary sequences widely distributed and filling the grabens of the MC. This continental sedimentation started in the Oligocene and most of the basins remain subsequently active. Miocene rocks are poorly consolidated conglomerate and sandstone and fluvial and lacustrine deposits. In the states of S. L. P., Zacatecas, and Guanajuato, these sequences are interbedded with Oligocene or Miocene felsic and mafic volcanic rocks (NietoSamaniego et al., 2007). Based on U-Pb zircon ages of silicic pyroclastic levels interbedded within fluvial and lacustrine sediments González-Cervantes et al. (2019) documented that sedimentation in the Aguascalientes and Teocaltiche grabens occurred between 28 and 7 Ma. Del Pilar-Martínez et al. (2020b) assigned a $16.5 \mathrm{Ma}$ maximum depositional age to poorly consolidated conglomerates in the San Felipe region from U-Pb detrital zircon ages of an interbedded tuffaceous sandstone.

Basaltic lavas from 14 to $7 \mathrm{Ma}$ also belong to the Miocene record (Luhr et al., 1995; Pérez-Venzor et al., 1996; AguirreDíaz et al., 1997; Cerca-Martínez et al., 2000; Henry and ArandaGómez, 2000; Angeles-Moreno, 2018). They form isolated outcrops with a wide distribution in the MC (Nieto-Samaniego et al., 2007; Tristán-González et al., 2009a). In S. L. P., these rocks were mapped as the Cabras basalt by Labarthe-Hernández (1982). In the southernmost MC they were grouped as Miocene basalts and define a hiatus between $22 \mathrm{Ma}$ and $16 \mathrm{Ma}$ (CercaMartínez et al., 2000; Alaniz-Álvarez et al., 2001). In the SG, this hiatus marks the cessation of the Sierra Madre Occidental silicic explosive volcanism and the inception of the mafic and effusive volcanism of the Transmexican Volcanic Belt (AngelesMoreno, 2018).

\subsection{Pliocene-Pleistocene}

Pliocene-Pleistocene intraplate volcanism related to extension with geochemical signals of the primitive mantle has been reported in S. L. P. and other sectors of the MC (Luhr et al., 1995; Aranda-Gómez et al., 2005; Aguillón-Robles et al., 2014). Such rocks are alkali basalts and contain mantle xenoliths and granulites from the lower crust. In northern S. L. P., LabartheHernández et al. (1982) defined these rocks as the Las Joyas Formation. On the other hand, Angeles-Moreno (2018) mapped in the SG a $1.16 \mathrm{Ma}$ silicic fall-air pyroclastic deposit named Las Pilas tuff. The best outcrops of this unit were documented by Suárez-Arias (2019) surrounding Ojuelos region and other minor exposures are in San Felipe region (Del Pilar Martínez et al., 2020b). A similar pyroclastic deposit, named El Desierto pumice, was reported by Labarthe-Hernández et al. (1982) in S. L. P. The source of this pyroclastic deposit is unknown, but it could come from some caldera structure hosted in the Transmexican Volcanic Belt (Del Pilar-Martínez, 2021).

\section{Conclusions}

We presented the first digital and interactive geological map of the whole southern sector of the Mesa Central province. It comprises part of the states of Guanajuato, San Luis Potosí, Jalisco, Aguascalientes, and Zacatecas, covering $41000 \mathrm{~km}^{2}$. The map shows the Cenozoic stratigraphy organized as lithostratigraphic and chronostratigraphic units, supported by a geochronological database of 261 isotopic ages. Also, the boundary and second-order Cenozoic faults are shown. The integration of these data in a single digital map makes it a valuable work tool for a better understanding of the geological evolution of Central Mexico.

\section{Acknowledgments}

We are grateful to Gilberto Silva Romo and Pablo Dávila Harris for their constructive reviews that substantially improved the original version. Penélope López Quiroz is gratefully acknowledged for the editorial support.

\section{Funding}

The research was funded by UNAM-PAPIIT IN102020 Grant to Ángel F. Nieto Samaniego. 
Geological map of the Cenozoic cover of the southern Mesa Central province, Mexico

Alexis Del Pilar-Martínez ${ }^{1,2}$, Ángel F. Nieto-Samaniego ${ }^{2}$, Edgar Angeles-Moreno ${ }^{3}$, Ana M. Suárez-Arias ${ }^{4}$, M.J.P. Olmos-Moya ${ }^{4}$, Susana A. Alaniz-Álvarez², Gilles Levresse ${ }^{2}$ ${ }^{1}$ Estación Regional del Noroeste, IGL-UNAM; ${ }^{2}$ Centro de Geociencias, UNAM; ${ }^{3}$ Depto. de Ingeniería en Minas, Metalurgia y Geologia, UG; ' ${ }^{4}$ Posgrado en Ciencias de la Tierra, CGEO-UNAM

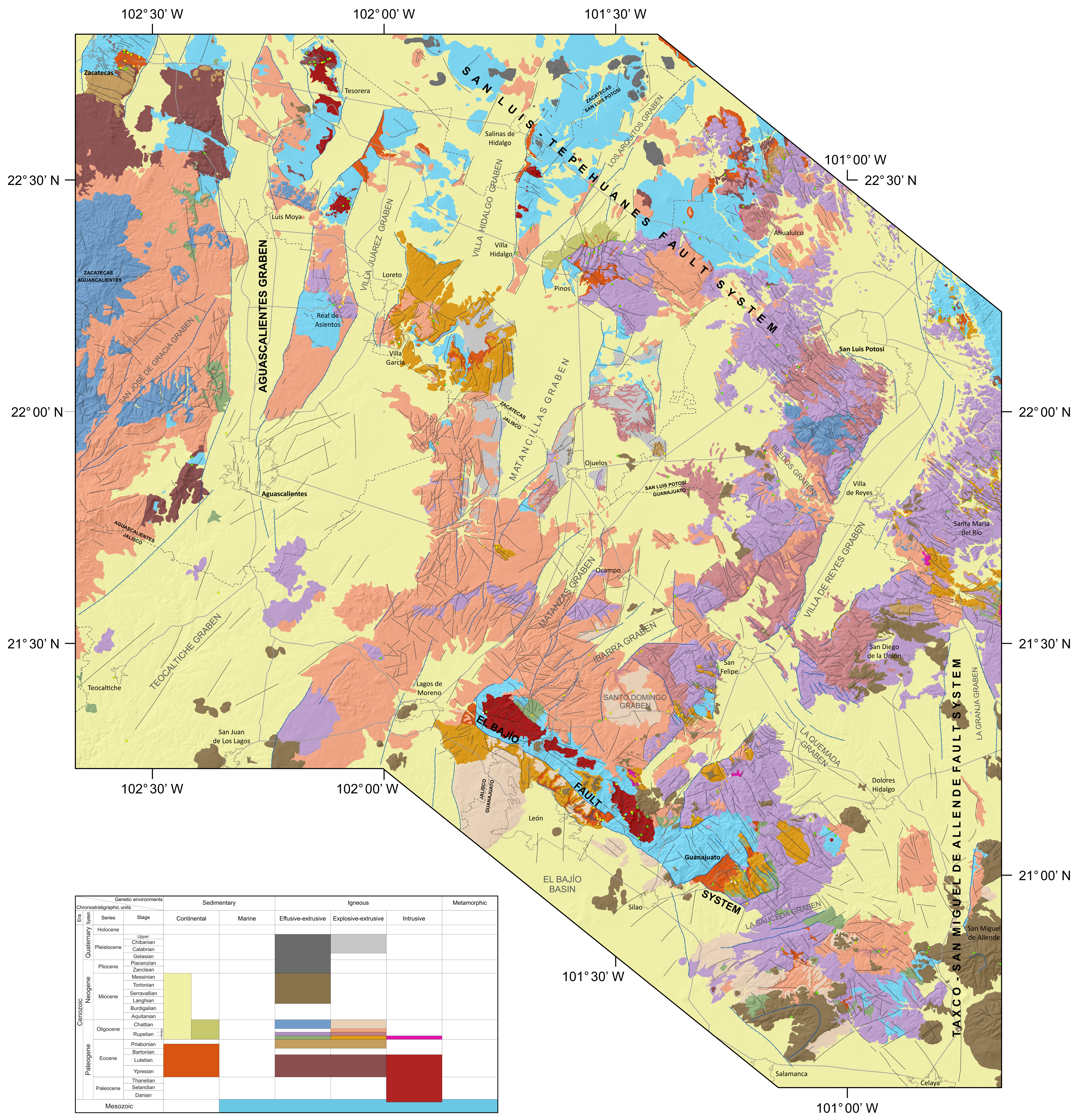

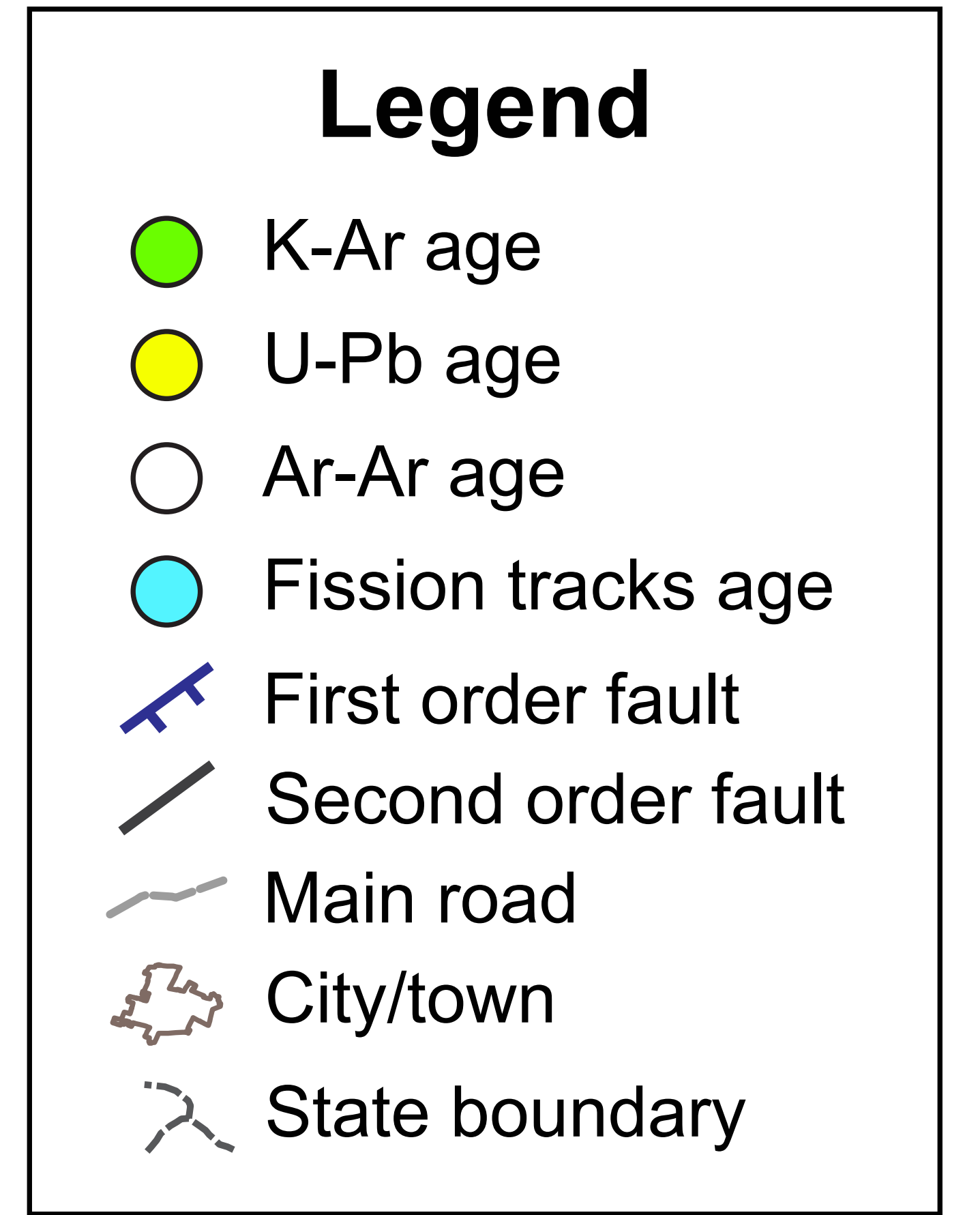
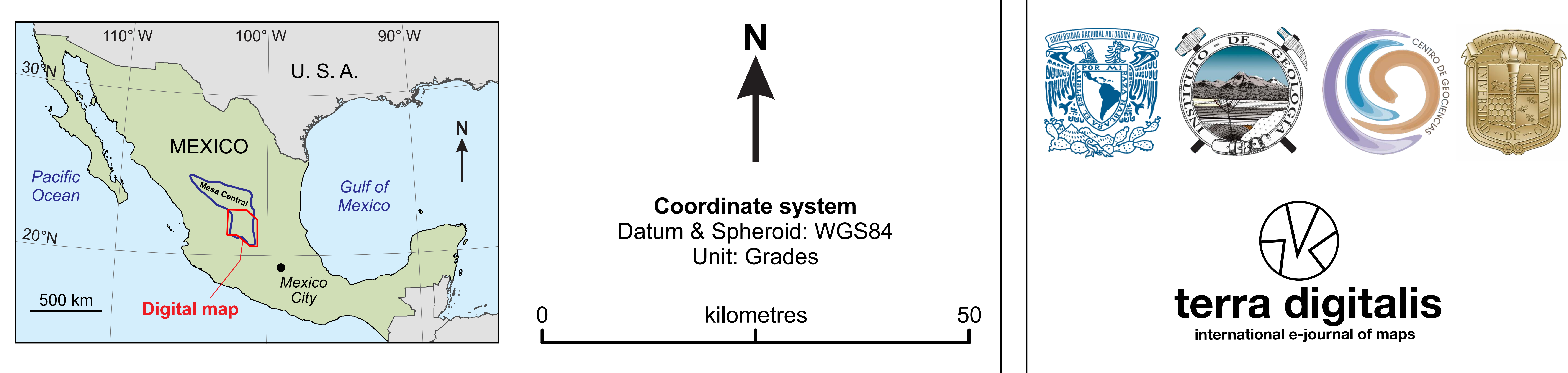


\section{References}

Aguillón-Robles, A., Tristán-González, M., Aguirre-Díaz, G. J., Bellon, H., 2009. Syn-extensional intra-plate trachydacite-rhyolitic dome volcanism of the Mesa Central, southern Sierra Madre Occidental volcanic province, Mexico. Journal of Volcanology and Geothermal Research 187 (1), 33-52, https://doi.org/10.1016/j.jvolgeores.2009.08.021.

Aguillón-Robles, A., Tristán-González, M., Aguirre-Díaz, G. J., López-Doncel, R. A., Bellon, H., Martínez-Esparza, G., 2014. Eocene to Quaternary mafic-intermediate volcanism in San Luis Potosí, central Mexico: The transition from Farallon plate subduction to intra-plate continental magmatism. Journal of Volcanology and Geothermal Research 276, 152-172, https://doi.org/10.1016/j.jvolgeores.2014.02.019.

Aguirre-Díaz, G. J., 1997. Ignimbrites of the central Mexican Volcanic Belt, Amealco and Huichapan Calderas (Querétaro-Hidalgo). En: Aguirre-Díaz, G. J., Aranda Gómez, J. J., Carrasco-Núñez, G., Ferrari, L. (Eds.), Magmatism and tectonics of central and northwestern Mexico; a selection of the 1997 IAVCEI General Assembly excursions. Universidad Nacional Autónoma de México, Instituto de Geología, México, D.F., pp. 1-39, excursión 1.

Aguirre-Díaz, G. J., Labarthe-Hernández, G., 2003. Fissure ignimbrites: Fissure-source origin for voluminous ignimbrites of the Sierra Madre Occidental and its relationship with Basin and Range faulting. Geology 31 (9), 773-776, https://doi.org/10.1130/G19665.1.

Alaniz-Alvarez, S. A., Nieto-Samaniego, A. F., Reyes-Zaragoza, M. A., Orozco-Esquivel, M. T., Ojeda-García, A. C., 2001. Estratigrafía y deformación extensional en la región San Miguel de Allende-Querétaro, México. Revista Mexicana de Ciencias Geológicas 18 (2), 129-148.

Angeles-Moreno, E., Nieto-Samaniego, A. F., Ruiz-González, F. J., Levresse, G., Alaniz-Alvarez, S. A., Olmos Moya, M. d. J. P., Xu, S., Miranda-Avilés, R., 2017. The transition between shortening and extensional regimes in central Mexico recorded in the tourmaline veins of the Comanja Granite. Journal of South American Earth Sciences 73, 65-77, https://doi.org/10.1016/j.jsames.2016.12.004.

Angeles-Moreno, Edgar, 2018. La evolución tectónica cenozoica de las sierras de Guanajuato y Codornices, México. doctoral thesis, Universidad Nacional Autónoma de México.

Aranda-Gómez, J. J., Luhr, J. F., Housh, T. B., Valdez-Moreno, G., ChávezCabello, G., 2005. El volcanismo tipo intraplaca del Cenozoico tardío en el centro y norte de México: una revisión. Boletín de la Sociedad Geológica Mexicana 57 (3), 187-225, https://doi.org/10.18268/bsgm2005v57n3a1.

Aranda-Gómez, J. J., Mcdowell, F. W., 1998. Paleogene Extension in the Southern Basin and Range Province of Mexico: Syndepositional Tilting of Eocene Red Beds and Oligocene Volcanic Rocks in the Guanajuato Mining District. International Geology Review 40 (2), 116-134, https://doi.org/10.1080/00206819809465201.

Aranda-Gómez, J. J., Molina-Garza, R., McDowell, F. W., Vassallo-Morales, L. F., Ortega-Rivera, M. A., Solorio-Munguía, J. G., Aguillón-Robles, A., 2007. The relationships between volcanism and extension in the Mesa Central: the case of Pinos, Zacatecas, Mexico. Revista mexicana de ciencias geológicas 24 (2), 216-233.

Botero-Santa, P. A., Alaniz-Alvarez, S. A., Nieto-Samaniego, A. F., LópezMartínez, M., Levresse, G., Xu, S., 2015. Origen y desarrollo de la cuenca El Bajío en el sector central de la Faja Volcánica Transmexicana. Revista mexicana de ciencias geológicas 32 (1), 84-98.

Cerca-Martínez, L. M., Aguirre Díaz, G. D. J., López-Martínez, M., 2000. The Geologic Evolution of the Southern Sierra de Guanajuato, Mexico: A Documented Example of the Transition from the Sierra Madre Occidental to the Mexican Volcanic Belt. International Geology Review 42 (2), 131-151, https://doi.org/10.1080/00206810009465073.

Cohen, K. M., Harper, D. A. T., Gibbard, P. L., 2021. ICS International Chronostratigraphic Chart 2021/05. International Commission on Stratigraphy, accessed: 2021-05-01. www.stratigraphy.org.

Cuéllar-Cárdenas, M. A., Nieto-Samaniego, A. F., Levresse, G., AlanizAlvarez, S. A., Solari, L., Ortega-Obregón, C., López-Martínez, M., 2012. Límites temporales de la deformación por acortamiento Laramide en el centro de México. Revista mexicana de ciencias geológicas 29 (1), 179-203.

Cuéllar-González, G., 2016. Control estructural de la mineralización del
Distrito Minero de Asientos Aguascalientes. Master's thesis, Universidad Autónoma de San Luis Potosí.

Del Pilar-Martínez, A., 2021. Evolución del sistema polimodal de fallas normales del sur de la Mesa Central de México: Implicaciones para el desarrollo de áreas afectadas por deformación triaxial frágil. doctoral tesis, Universidad Nacional Autónoma de México.

Del Pilar-Martínez, A., Nieto-Samaniego, A. F., Alaniz-Alvarez, S. A., 2020a. Development of a Brittle Triaxial Deformation Zone in the Upper Crust: The Case of the Southern Mesa Central of Mexico. Tectonics 39 (11), e2020TC006166, https://onlinelibrary.wiley.com/doi/pdf/10.1029/2020TC006166.

Del Pilar-Martínez, A., Nieto-Samaniego, A. F., Alaniz-Alvarez, S. A., Angeles-Moreno, E., 2020b. Geology of the southern Mesa Central of Mexico: recording the beginning of a polymodal fault system. Journal of Maps 16 (2), 199-211, https://doi.org/10.1080/17445647.2020.1719911.

Del Río Varela, P., Nieto-Samaniego, A. F., Alaniz-Alvarez, S. A., AngelesMoreno, E., Escalona-Alcázar, F. d. J., Pilar-Martínez, A. d., Río Varela, P. d., Nieto-Samaniego, A. F., Alaniz-Alvarez, S. A., Angeles-Moreno, E., Escalona-Alcázar, F. d. J., Pilar-Martínez, A. d., 2020. Geología y estructura de las sierras de Guanajuato y Codornices, Mesa Central, México. Boletín de la Sociedad Geológica Mexicana 72 (1), A071019, https://doi.org/10.18268/bsgm2020v72n1a071019.

Díaz-Bravo, B. A., Barboza-Gudiño, J. R., Ortega-Obregón, C., Morales-Gámez, M., 2021. Late Cretaceous to Oligocene overlapping plutonic magmatism episodes in the eastern Mesa Central province of Mexico. International Geology Review 0 (0), 1-23, https://doi.org/10.1080/00206814.2021.1871866.

Edwards, J. D., 1955. Studies of some early Tertiary red conglomerates of central Mexico. Professional Paper 264-H, 183, https://doi.org/10.3133/pp264H.

Escalona-Alcázar, F. d. J., Solari, L., García y Barragán, J. C., CarrilloCastillo, C., Bluhm-Gutiérrez, J., García-Sandoval, P., Nieto-Samaniego, A. F., Nuñez-Peña, E. P., 2016. The Palaeocene-early Oligocene Zacatecas conglomerate, Mexico: sedimentology, detrital zircon $\mathrm{U}-\mathrm{Pb}$ ages, and sandstone provenance. International Geology Review 58 (7), 826-848, https://doi.org/10.1080/00206814.2015.1125809.

Ferrari, L., Lopez-Martinez, M., Rosas-Elguera, J., 2002. Ignimbrite flare-up and deformation in the southern Sierra Madre Occidental, western Mexico: Implications for the late subduction history of the Farallon plate. Tectonics 21 (4), 17-1-17-24, https://onlinelibrary.wiley.com/doi/pdf/10.1029/2001TC001302.

Ferrari, L., Valencia-Moreno, M., Bryan, S., 2007. Magmatism and tectonics of the Sierra Madre Occidental and its relation with the evolution of the western margin of North America. En: Alaniz-Alvarez, S. A., Nieto-Samaniego, A. F. (Eds.), Geology of México: Celebrating the Centenary of the Geological Society of México. Vol. 422 of Geological Society of America Special Papers. Geological Society of America, Boulder, Col., USA, pp. 1-39, https://doi.org/10.1130/2007.2422(01).

Fitz-Díaz, E., Lawton, T. F., Juárez-Arriaga, E., Chávez-Cabello, G., 2018. The Cretaceous-Paleogene Mexican orogen: Structure, basin development, magmatism and tectonics. Earth-Science Reviews 183, 56-84, https://doi.org/10.1016/j.earscirev.2017.03.002.

Franzetti, M., 2009. Contribution à l'étude des massifs plutoniques de la Tesorera et de la Sauceda, Mexique. mémoire master 1, Université de Bretagne Occidentale, Brest, France.

García-Ruíz, J. M., Avila-Ramos, F. J., 1999. Carta Geológico-Minera Lagos de Moreno F14-C31, 1:50 000.

González-Cervantes, N. G., Aranda-Gómez, J. J., Carranza-Castañeda, O. C., Ortega-Obregón, C., 2019. Edad y origen de la paleocuenca continental de Teocaltiche, México. Revista Mexicana de Ciencias Geológicas 36 (3), 393410, https://doi.org/10.22201/cgeo.20072902e.2019.3.1391.

GYMSA, Estudios de Planeación Regional S.A. de C.V., 2001. Carta Geológico-Minera Luis Moya F13-B79, 1:50 000.

Gámez-Ordaz, V., Avila-Ramos, F. J., 2017. Carta Geológico-Minera Melchor F14-C24, 1:50 000.

Henry, C. D., Aranda-Gomez, J. J., 2000. Plate interactions control middle-late Miocene, proto-Gulf and Basin and Range extension in the southern Basin and Range. Tectonophysics 318, 1-26, https://doi.org/10.1016/S00401951(99)00304-2. 
Hernández-Loredo, A., 2007. Carta Geológico-Minera Salinas de Hidalgo F14A61, 1:50 000.

Labarthe-Hernández, G., Tristán-González, M., Aranda-Gómez, J.J., 1982. Revisión estratigráfica del Cenozoico de la parte central del Estado de San Luis Potosí. Folleto Técnico No. 85, Universidad Autónoma de San Luis Potosí, Instituto de Geología y Metalurgia.

Loza-Aguirre, I., Nieto-Samaniego, A. F., Alaniz-Alvarez, S. A., Iriondo, A., 2008. Relaciones estratigráfico-estructurales en la intersección del sistema de fallas San Luis Tepehuanes y el graben de Aguascalientes, México central. Revista mexicana de ciencias geológicas 25 (3), 533-548.

Luhr, J. F., Pier, J. G., Aranda-Gómez, J. J., Podosek, F. A., 1995. Crustal contamination in early Basin-and-Range hawaiites of the Los Encinos Volcanic Field, central México 118, 321-339, https://doi.org/10.1007/s004100050018.

Martínez-Reyes, J., 1992. Mapa geológico de la Sierra de Guanajuato con resumen de la geología de la Sierra de Guanajuato.

Miranda-Avilés, R., Puy-Alquiza, M. J., Omaña, L., Loza-Aguirre, I., 2016. Los depósitos clásticos pos-Laramide de la Sierra de Guanajuato: Implicaciones de su composición en la evolución tectonosedimentaria y paleogeográfica. Estudios Geológicos 72 (2), e058, https://doi.org/10.3989/egeol.42480.417.

Montañez-Castro, A., Bustos-Gutiérrez, L. A., 2002. Carta Geológico-Minera Loreto F14-A71, 1:50 000.

Nieto-Samaniego, A. F., Alaniz-Alvarez, S. A., Camprubí, A., 2007. Mesa Central of México: Stratigraphy, structure, and Cenozoic tectonic evolution. En: Alaniz-Alvarez, S. A., Nieto-Samaniego, A. F. (Eds.), Geology of México: Celebrating the Centenary of the Geological Society of México. Vol. 422 of Geological Society of America Special Papers. pp. 41-70, 10.1130/2007.2422(02).

Nieto-Samaniego, A. F., Ferrari, L., Alaniz-Alvarez, S. A., LabartheHernández, G., Rosas-Elguera, J., 1999. Variation of Cenozoic extension and volcanism across the southern Sierra Madre Occidental volcanic province, Mexico. GSA Bulletin 111 (3), 347-363, https://doi.org/10.1130/0016-7606(1999)111<0347:VOCEAV>2.3.CO;2.

Nieto-Samaniego, A. F., Macías Romo, C., Alaniz Alvarez, S. A., 1996. Nuevas edades isotópicas de la cubierta volcánica cenozoica de la parte meridional de la Mesa Central, México. Revista mexicana de ciencias geológicas 13 (1), $117-122$.

Nieto-Samaniego, A. F., Olmos-Moya, M. d. J. P., Levresse, G., AlanizAlvarez, S. A., Abdullin, F., Del Pilar-Martínez, A., Xu, S., 2020. Thermochronology and exhumation rates of granitic intrusions at Mesa Central, Mexico. International Geology Review 62 (3), 311-319, https://doi.org/10.1080/00206814.2019.1602789.

Olmos-Moya, M. J .P., 2016. Estratigrafía y estructuras cenozoicas del frente suroeste de la Sierra de Guanajuato. bachelor thesis, Universidad de Guanajuato, Departamento de Minas, Metalurgia y Geología.

Orozco-Esquivel, M. T., Nieto-Samaniego, A. F., Alaniz-Alvarez, S. A., 2002. Origin of rhyolitic lavas in the Mesa Central, Mexico, by crustal melting related to extension. Journal of Volcanology and Geothermal Research 118 (1), 37-56, https://doi.org/10.1016/S0377-0273(02)00249-4.

Ponce, B. F. S., Clark, K. F., 1988. The Zacatecas mining district: A Tertiary caldera complex associated with precious and base metal mineralization. Economic Geology 83 (8), 1668-1682, https://doi.org/10.2113/gsecongeo.83.8.1668.

Procesos Analíticos Informáticos S.A. de C.V., 2008. Carta Geológico-Minera San Diego de la Unión F14-C34, 1:50 000.

Pérez-Vargas, M. A., López-Ojeda, J. A., Alvarado-Méndez, H., SaldañaSaucedo, G., 1996. Carta Geológico-Minera Dolores Hidalgo F14-C44, 1:50 000 .

Pérez Venzor, J. A., Aranda Gómez, J. J., McDowell, F., Solorio Munguía,
J. G., 1996. Geología del volcán Palo Huérfano, Guanajuato, México. Revista mexicana de ciencias geológicas 13 (2), 174-183.

Rodríguez-Ríos, R., Tristán-González, M., Aguillón-Robles, A., 2013. Estructura y geoquímica de un grupo de domos dacíticos del norponiente del campo volcánico de San Luis Potosí, México. Boletín de la Sociedad Geológica Mexicana 65 (1), 109-122, http://dx.doi.org/10.18268/BSGM2013v65n1a9.

Romo-Ramírez, J.R., 2007. Carta Geológico-Minera Espíritu Santo F14-A62, 1:50 000 .

Ruiz-González, F.J., 2015. Estudio de las vetas de turmalina que registran la historia de exhumación del Granito Comanja, Sierra de Guanajuato, México. Master's thesis, Universidad Nacional Autónoma de México.

Sieck, P., Dávila-Harris, P., López-Doncel, R. A., Almaguer, J., AguillónRobles, A., Wemmer, K., Guevara, R., 2021. Voluminous Paleogene volcanism in the southern Mesa Central, Mexico: Unravelling the fissurefed origin of rhyolitic ignimbrites of the Villa Garcia-Loreto Volcanic Complex. Journal of Volcanology and Geothermal Research 415, 107252, https://doi.org/10.1016/j.jvolgeores.2021.107252.

Sociedad Exploradora Minera S.A. de C.V., 1999a. Carta Geológico-Minera Ojo Caliente F13-B69, 1:50 000.

Sociedad Exploradora Minera S.A. de C.V., 1999b. Carta Geológico-Minera Pinos F14-A72, 1:50 000.

Suárez-Arias, A.M., 2019. Edad, cinemática y fases de actividad del semigraben de Matancillas, Ojuelos, Jal., México. Master's thesis, Universidad Nacional Autónoma de México.

Torres-Hernández, J. R., Labarthe Hernández, G., Aguillón Robles, A., Gómez Anguiano, M., Mata Segura, J. L., 2006. The pyroclastic dikes of the Tertiary San Luis Potosí volcanic field: Implications on the emplacement of Panalillo ignimbrite. Geofísica internacional 45 (4), 243-253.

Torres, J., Rojas-Escudero, I., Salas-Hernández, H., Ocejo-Paredes, T., 2001. Carta Geológico-Minera Rincón de Romos F13-B89, 1:50 000.

Tristán-González, M., Aguillón-Robles, A., Barboza-Gudiño, J. R., CruzMárquez, J., García-Arreola, M. E., Bellon, H., Franzetti, M., Labarthe-Hernández, G., 2015. Características geoquímicas y significado tectónico del complejo de diques y domos félsicos del Paleoceno-Eoceno de La Tesorera, Zacatecas, en la Mesa Central, México. Revista mexicana de ciencias geológicas 32 (3), 455-474, https://doi.org/10.22201/cgeo.20072902e.2015.3.594.

Tristán-González, M., Aguillón-Robles, A., Barboza-Gudiño, J. R., TorresHernández, J. R., Bellon, H., López-Doncel, R., Rodríguez-Ríos, R., Labarthe-Hernández, G., 2009a. Geocronología y distribución espacial del vulcanismo en el Campo Volcánico de San Luis Potosí. Boletín de la Sociedad Geológica Mexicana 61 (3), 287-303, http://dx.doi.org/10.18268/BSGM2009v61n3a1.

Tristán-González, M., Aguirre-Díaz, G. J., Labarthe-Hernández, G., Torres-Hernández, J. R., Bellon, H., 2009b. Post-Laramide and pre-Basin and Range deformation and implications for Paleogene (55-25 Ma) volcanism in central Mexico: A geological basis for a volcano-tectonic stress model. Tectonophysics 471 (1), 136-152, https://doi.org/10.1016/j.tecto.2008.12.021.

Xu, S. S., Nieto-Samaniego, A. F., Alaniz-Alvarez, S. A., 2013. Emplacement of pyroclastic dykes in Riedel shear fractures: An example from the Sierra de San Miguelito, central Mexico. Journal of Volcanology and Geothermal Research 250, 1-8, https://doi.org/10.1016/j.jvolgeores.2012.10.010.

This article accompanies the following material:

Static map:

Interactive map:

Suppl. Material: 10.22201/igg.25940694e.2021.2.89.187

10.22201/igg.25940694e.2021.2.89.188

10.22201/igg.25940694e.2021.2.89.193 